\title{
Prediction Soil Erosion Using GIS-USLE Under Different Land Uses In West Timor, Indonesia
}

\author{
Yofris Puay ${ }^{1}$, Stefanus M. Kuang ${ }^{1}$, Melinda R.S. Moata ${ }^{1, *}$, Senawi ${ }^{2}$, Ambar Kusumandari ${ }^{2}$ \\ \{orispuay@yahoo.com, stef130976@yahoo.co.id, rosita.moata@gmail.com, \\ senawi@ugm.ac.id,ambar_kusumandari@yahoo.com \} \\ Kupang state of Agricultural Polytechnic, Indonesia ${ }^{1}$ \\ Universitas Gadjah Mada, Faculty of Forestry, Indonesia ${ }^{2}$
}

\begin{abstract}
Transformation of land uses from several semi-arid agroecosystems in Indonesia: forest to settlement, dryland agriculture, and others had affected to soil erosion. This study was conducted to evaluate soil erosion at semi-arid Manikin Baki watershed, West Timor, Indonesia. USLE method was used to predict soil erosion supporting ArcGIS 10.3 software. The results showed that the highest soil erosion occurred at dryland farming $(60.22 \%$ with total land cover $11 \%$ of total areas), while the smallest one went to the forest $(0.20 \%$ with total land cover $42 \%$ of total areas). Another finding that soil erosion at Manikin Baki watershed was dominated by class I $(12,251.77 \mathrm{Ha} ; 64.38 \%$ of total areas), while the smallest one was majored for class IV (1.59\% of total areas).
\end{abstract}

Keywords: dryland farming, mixed cropping, forest land, GIS, USLE

\section{Introduction}

There are numbers of definition for dryland: upland, rainfed agriculture or unirrigated land. In general, dryland has a steep slope, sallow soil depth, and hilly-mountainous areas. Dryland with a steep slope and low soil depth could provide high potential of soil erosion risk and lack of water. Therefore agricultural practices only could be applied once a year [1]. According to geographic and agroclimatic position, East Nusa Tenggara (ENT) Province belongs to dryland in a semi-arid region. In 2015, the Central Bureau of Statistics (BPS) reported total dryland in ENT province was about 3,584,394 $\mathrm{Ha}(94 \%)$, while wetland (paddy field) was $210,774 \mathrm{Ha}(6 \%)$. Some West Timor soils were prone of erosion risk due to moderate to high erodibility of soil. However, it has to support about 5 million people who recognized as the most top stunting problem (40.3\%) nationally. According to climatic type Schmidt-Ferguson, ENT belongs to type D (moderate, vegetation on rainy season), $\mathrm{E}$ (semi-arid, vegetation savanna forest), and $\mathrm{F}$ (dryland, vegetation savanna forest). Its soils are mostly lack of soil organic matter [2].

Semi-arid Manikin Baki watershed is one area which potential of soil erosion risk located in Kupang regency, West Timor-Indonesia about 19,000 Ha. This area consists of 19 villages where 
the basin became a vital source of water and land for rural people, especially at downstream. Any activity at upstream would affect social, cultural, and economics of people at downstream. For instance, lack of groundwater and high run off due to land-use change. Although this region has climate type E (semi-arid), but it still high risk of erosion. Soil erosion was supported by high intensity of rainfall at rainy season $\left(1000-2000 \mathrm{~mm}\right.$ yr-1), slope gradient $\left(>15^{\circ}\right)$, soil depth $(<$ $1 \mathrm{~m}$ ), and less soil conservation practices. Land use changes from forest to cropping land at upstream (Baumata and Oeltua villages), and settlement (housing) were also other reasons [3]. The settlement in this context means house with a little yard (field) for cropping. Since the settlement could also include in soil erosion equation as a socioeconomic factor [4].

One study for global assessment indicated that Southeast Asia is one of the prone areas to soil erosion due to land-use change [5]. There are some reasons for dryland degradation in West Timor-Indonesia: pollution, intensive agriculture, soil erosion, un-suitable land uses, lack of fertile soil and water because of soil compaction, stony soil, and lack of organic matter, as defined by [6]. Type of farming systems had shown to effect on soil nutrients depletion in Ghana and recommended to apply legume crops to reduce soil erosion [7]. Not only land-use changes but also atmospheric $\mathrm{CO} 2$ and climate change had also affected to decreasing of soil organic carbon by soil erosion [8].

Soil erosion had become one of the serious problems not only for the environment but also community [9], [10] because it is related to world food production [9]. About 10 million Ha agricultural lands had loss annually due to erosion, which affects to reduce food production [10] or $75 \%$ of fertile soil from soil surface loss due to soil erosion, and resulted in the decreasing of soil depth and soil fertility $[9,10]$. Soil diminishing from agricultural land was 10-40 times faster than its formation. Ironically, at the same time when all sectors are focusing on improving crop production, on the other hand, land degradation is also increasing over the world. When population growth is increasing, food production per capita is also decreasing [11], approximately $35 \%$ surface soil was prone to soil erosion, and almost one-third of world agricultural land was lost due to erosion [9]. Thus, chosen for soil and water conservation practices become crucial to overcome all the risks on soil erosion (nutrient loss, soil moisture, income, and crop yield), as suggested by [12], agroforestry and vegetative barriers systems and applying proper technology [13]

Eventually, soil erosion is crucial for dryland in a semi-arid region where has limited arable land and high topography but have to supply enough production and quality of foods. Therefore, this study was conducted to estimate soil erosion at a semi-arid watershed in West Timor at various land uses.

\section{Materials and Methods}

This study was conducted through four steps (field survey, observation, data collection, and data analysis). Field survey and observation were conducted in February 2018 at Manikin Baki watershed to determine land cover and land uses from upstream to downstream areas. Primary and secondary data were also prepared to get more information before establishing fieldwork maps. A land unit map is from overlay soil, slope, and land uses maps, then produced land units (area 
samples). Soil and slopping maps used in this study was Kupang regency soil map scale 1:350.000 from Watershed Management Bureau of Benain Noelmina (2012). Land use map was produced from satellite imagery SPOT 6, recorded in 2018 and ground checked.

Data collection was done by collecting all primary data such as slopping, soil depth, soil structure, land uses, and soil conservation practices. Climate data was collected from Geophysics and Meteorology Board of ENT from surrounding stations: Naibonat, Oekabiti, Baun, Naioni, Maulafa and Kelapa Lima stations for 13 years (2004 - 2017). Soil samples were also collected from each field (area samples) at $0-30 \mathrm{~cm}$ to analyze soil texture, organic matter, permeability, and soil mass.

Soil erosion could be calculated by numbers of equations (EPM, USLE, Koutsoyiannis and Tarla, RUSLE) [14]. This study used combination GIS/USLE methods [15], [16], [17], A= RKLSCP. Rainfall erosivity (R) uses equation of Bols (1978) in [18] $\mathrm{R}=38,8+0,35$ (annual rainfall-mm). Annual rainfall data for last 13 years (2004 - 2017) were collected from BMKG (Geophysics, Climatology and Meteorology Bureau) Kupang regency. Soil erodibility (K) uses Hammer $(1978) \mathrm{K}=[2,173 \mathrm{M} 1.14(10-4)(12-a)+3,25(b-2)+2,5(c-3)] / 100$, where M (soil particle size $\%$ silt+\% fine sand) $\mathrm{x}(100-\%$ clay), a (organic matter $=\% \mathrm{C} \times 1,724), \mathrm{b}$ (code of soil structure), and c (code of soil permeability). Soils were collected at $0-30 \mathrm{~cm}$ depth and analyzed particles size, organic matter, soil structure, and soil permeability at soil laboratory. Factor length and steep slope (LS) were determined based on the steeps (\%): 0-8\%, 8-15\%, 15-25\%, 25-45\%, > 45\% (LS 0.25, $1.20,4.25,9.50,12.0$, respectively). The steep slope was observed directly in the field and compared to GIS map. The factor of land cover/vegetative and conservation (CP) was determined based on field observation and used classification by Ministry of Public Work (2012) (Table 1).

Table 1. Factor of land cover/vegetation and conservation (CP).

\begin{tabular}{|c|c|c|c|c|c|}
\hline \multirow[t]{2}{*}{ No. } & \multirow[t]{2}{*}{ Land cover } & \multicolumn{4}{|c|}{ Slope classification/ CP } \\
\hline & & $\overline{0-2 \%}$ & $2-15 \%$ & $15-40 \%$ & $>40 \%$ \\
\hline 1. & The settlement & 0.0500 & 0.0500 & 0.0500 & 0.0500 \\
\hline 2. & Irrigated rice field & 0.0100 & 0.0100 & 0.0100 & 0.0250 \\
\hline 3. & Rainfed rice field & 0.0445 & 0.0625 & 0.0955 & 0.1365 \\
\hline 4. & Nursery & 0.0045 & 0.0104 & 0.0199 & 0.0338 \\
\hline 5. & Agro forestry & 0.0223 & 0.0313 & 0.0478 & 0.0683 \\
\hline 6. & Natural forest & 0.0002 & 0.0005 & 0.0010 & 0.0010 \\
\hline 7. & Production Forest & 0.0010 & 0.0010 & 0.0020 & 0.0020 \\
\hline 8. & Shrubs & 0.0010 & 0.0015 & 0.0020 & 0.0020 \\
\hline 9. & Savanna (grassing) & 0.0050 & 0.0100 & 0.0020 & 0.0020 \\
\hline 10. & Bare ground & 1.0000 & 1.0000 & 1.0000 & 1.0000 \\
\hline
\end{tabular}

Source: Ministry of Public Work, 2012. 
Eventually, estimation of soil erosion was determined based on erosion level classification (Director of Land Reforestation and Rehabilitation No.041/Kpts/1998): class I, II, III, IV (< 15, 15-60, 60-180, 180-480, > 480 tha-1 year-1, respectively).

Land unit is a unit mapping analysis based on similar physical land characteristics. This study produced land unit mapping based on overlay three parameters (slopes, land uses, and soil type) using ArcGIS 10.3. The maps were used for deciding sample locations. There are six types of land uses used in this study (dryland cropping, forest, grassing- shrub, agroforestry, paddy field, and the settlement).

The erosion level was also determined at a unit land level. It resulted that from 141 land units, some of the body water (pond, check dam, and wetland) were ignored. Additionally, for the land that has total area $<10 \mathrm{Ha}$ and airport area were also eliminated from picked samples. Finally, it resulted in about 89 land units with total 18,634 Ha to be analyzed. Finally, all of 89 land units were overlaid with rainfall erosivity (three classes using isoerodent) then produced 287 points. All data were analyzed using Microsoft Excel.

\section{Results and Discussion}

Total soil erosion at Manikin Baki watershed was approximately 41,008 tons for total 18,634 Ha (average $2.20 \mathrm{t}$ ha-1 year-1). The most extensive land areas at Manikin Baki watershed (Figure 1) was forest land $(42 \% ; 7,767 \mathrm{Ha})$, and the smallest was paddy field $(6 \%$; $1,067 \mathrm{Ha})$. Forest land has been occupied almost half of the total land cover $(42 \%)$, but it has proven to be the lowest soil erosion level ( $82 \mathrm{t}$ ha-1 year-1) (Figure 2a,b). On the other hand, dryland cropping although only $11 \%$ of entire land cover, it had produced the highest soil erosion level $(24,79$ t ha-1 year-1) or $61 \%$ of soil erosion (Figure 2a,b).

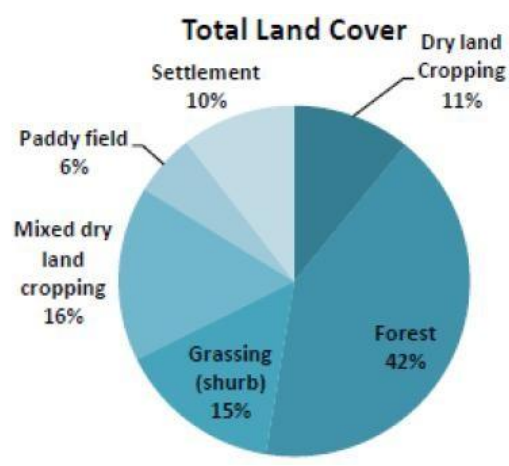

Fig. 1. Composition of total land areas per land uses (\%) 


\section{Erosion Level}

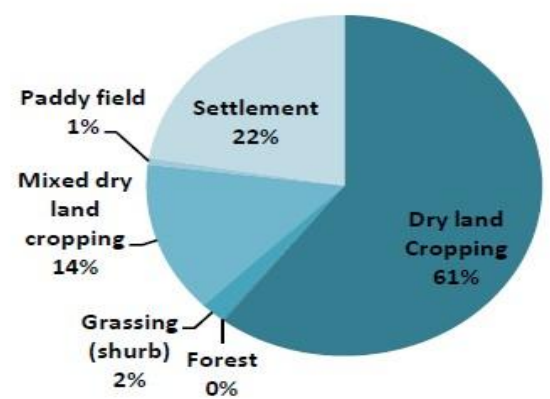

Figure 2a. Proportion soil erosion per land uses (ton. $\mathrm{h}^{-1} \cdot \mathrm{y}^{-1}$ ).

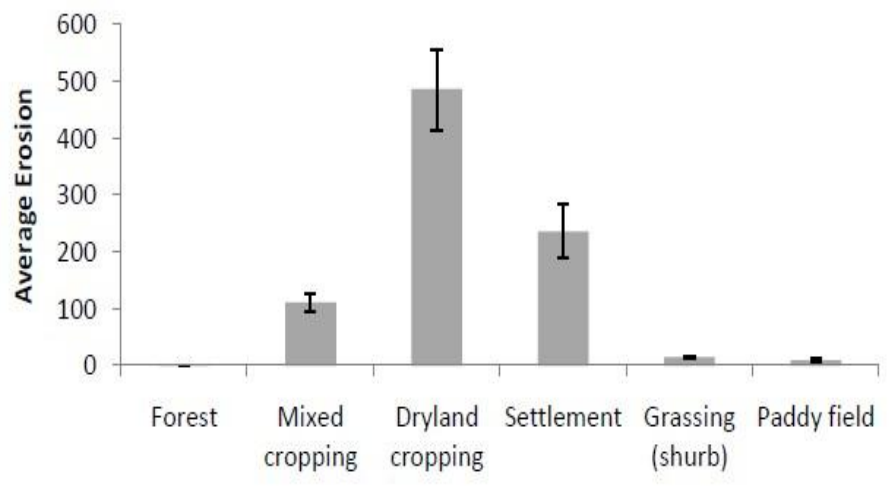

Figure 2b. Mean soil erosion per land uses with SE bars.

The local farming system, as commonly applied by all West Timor people was dryland cropping with dominant crops such as maize, cassava, banana, and beans. They used to apply slash and burn practices annually at forest land and grassing/shrublands towards rainy season (SeptemberOctober). The main reason for doing that was to clean up all the land even from woody/annual trees as competitor plants and biomasses before planting. Thus, this is prone to soil erosion. Uncover surface soil with rare plants will effect to increase detachment particle soil, transportation, and sedimentation at new places. Conventional practices slash and burn could increase availability $\mathrm{P}$ [19], but it had affected on the changes of soil properties (physical, chemical and biological properties) of forest soils, and promoted leaching and erosion [20]. Soil losses due to run off could 
reach 45-57 t ha-1 (40-50 times compare to no burnt soil) with total runoff $142-181 \mathrm{~mm}$ of 1,636 $\mathrm{mm}$ total rainfall and nutrients losses (N-265-290 kg.h-1, P-23-28 kg.h-1,K-1380-1710 kg.h-1) [19]. In addition, the burned soil could also reduce infiltration, porosity, sorptivity and hydraulic conductivity [21], changes of soil mineralogy for all fire intensity [22]. Thus, it is indicated that soils with slash and burn practices had impacted land degradation (erosion).

Additionally, relief, land uses, and soil factors were other important factors that affect soil erosion at to semi-arid region. Manikin Baki watershed is mainly covered by hills with steep slope $>15 \%$, affect to increase runoff. Land use for settlement also has rare plants comparable to dryland agriculture which support soil erosion, as well as high soil erodibility factor (Table 2.). As found in this study that cropping provided the highest erosion $(24,79 \mathrm{t}$ ha-1 year-1) as well to other cultivations, like wheat lands (17.6 t km-2 yr-1) [23], cereal agriculture [24]. One case study in China, they defined land-use types and erosion level in order cropland $>$ pastureland $>$ woodland $>$ grassland > shrubland [25], as well as in Turkey in which cropland > grasslandd > recreation > plantation and > forest [17] these comparable to our results cropping > settlement $>$ mixed cropping (agroforestry) $>$ shrub $>$ paddy field $>$ forest. This showed that human-induced transformation of land uses impacted to soil erosion nearly $60 \%$ [26].

Meanwhile, forest land has shown to have the lowest soil erosion compared to other land uses. Forest at semi-arid especially surrounding the watershed was dominated by woody trees like jati (Tectona grandis), mahoni (Swietenia macrophila), gamalin (Gmelina arborea), kabesak (Acacia leucophaloea), johar (Senna siamea), and sengon (Paraseriantes falcataria). Those type of plants have depth roots system, full crop header (shoot system), stratification shoot system, and producing high biomass that could add organic matter, improve soil structure and soil permeability. Thus, forest land has a lower soil erosion risk at a semi-arid watershed. Besides, grassing (shrub) and paddy field was also provided more moderate erosion due to the surface covering intensity.

Table 2. Statistic Description, mean of $A=($ RKLSCP).

\begin{tabular}{lcccccccc}
\hline \multicolumn{1}{c}{ Land uses } & $\mathbf{n}$ & $\mathbf{R}$ & $\mathbf{K}$ & $\mathbf{L S}$ & $\mathbf{C P}$ & $\begin{array}{c}\mathbf{A} \\
\left(\mathrm{t} . \mathrm{ha}^{-1} \cdot \mathrm{y}^{-1}\right)\end{array}$ & SD & SE \\
\hline Forest & 60 & 604 & 0,76 & 3 & 0,001 & 1 & 1 & 0 \\
Mixed cropping & 53 & 602 & 0,81 & 3 & 0,080 & 111 & 116 & 16 \\
Dryland cropping & 51 & 608 & 0,84 & 3 & 0,388 & 486 & 507 & 71 \\
Settlement & 39 & 603 & 0,83 & 2 & 0,200 & 236 & 294 & 47 \\
Grassing (shurb) & 57 & 606 & 0,77 & 3 & 0,010 & 14 & 5 & 1 \\
Paddy field & 27 & 616 & 0,89 & 2 & 0,010 & 9 & 10 & 2 \\
\hline Total & 287 & & & & & & &
\end{tabular}

n (sample size); R (rainfall erosivity); K (soil erodibility); LS (length \& slope); CP (vegetation \& conservation); A (actual erosion); SD (standard deviation); SE (standard error).

Ultimately, refer to Director of Land Reforestation and Rehabilitation No.041/Kpts/1998 about classification of soil erosion, class I was the widest soil erosion in terms of land cover 
(64.38\%) with the lowest amount of soil erosion (1.1\%), while Class V with high risk of soil erosion was only $1.59 \%$ of total land cover (Table 3 ).

Table 3. Classification of soil erosion at Manikin Baki Watershed.

\begin{tabular}{|c|c|c|c|c|c|c|}
\hline No. & $\begin{array}{l}\text { Soil Erosion } \\
\left(\mathrm{t} \cdot \mathrm{h}^{-1} \cdot \mathrm{y}^{-1}\right)\end{array}$ & $\begin{array}{c}\text { Classes of soil } \\
\text { erosion }\end{array}$ & $\begin{array}{c}\text { Amount of } \\
\text { soil } \\
\text { erosion } \\
\left(\mathrm{t} \cdot \mathrm{h}^{-1} \cdot \mathrm{y}^{-1}\right)\end{array}$ & $\begin{array}{l}\text { Percentage } \\
(\%) \text { of soil } \\
\text { erosion }\end{array}$ & Land areas $(\mathrm{Ha})$ & $\begin{array}{c}\text { Percentage } \\
(\%) \text { of soil } \\
\text { erosion }\end{array}$ \\
\hline 1. & $<15$ & I & 456.39 & 1.10 & 12251.77 & 64.38 \\
\hline 2. & $15-60$ & II & 2477.77 & 6.01 & 4286.07 & 22.52 \\
\hline 3. & $60-180$ & III & 3637.55 & 8.83 & 1253.75 & 6.59 \\
\hline 4. & $180-480$ & IV & 7747.20 & 18.81 & 935.93 & 4.92 \\
\hline 5. & $>480$ & V & 26850.05 & 65.21 & 302.89 & 1.59 \\
\hline
\end{tabular}

Soil erosion at class IV (heavy) and V (very heavy) depend on soil depth. Even though, those classes placed only $7 \%$ but still need to think seriously for the loss of soil at the land 1,239 $\mathrm{Ha}$, especially those areas are part of catchment areas (Figure 3). This number would increase over a period of time if there were no conservation technology practices. Thus, it will affect to the decreasing of clean water at downstream areas which are the capital city of ENT (Kupang) and several villages in Kupang regency. Regarding this problem, as suggested by [12], strong commitment from the government by providing regulation, infrastructure, and service will encourage local farmers to apply a sustainable land management system. 


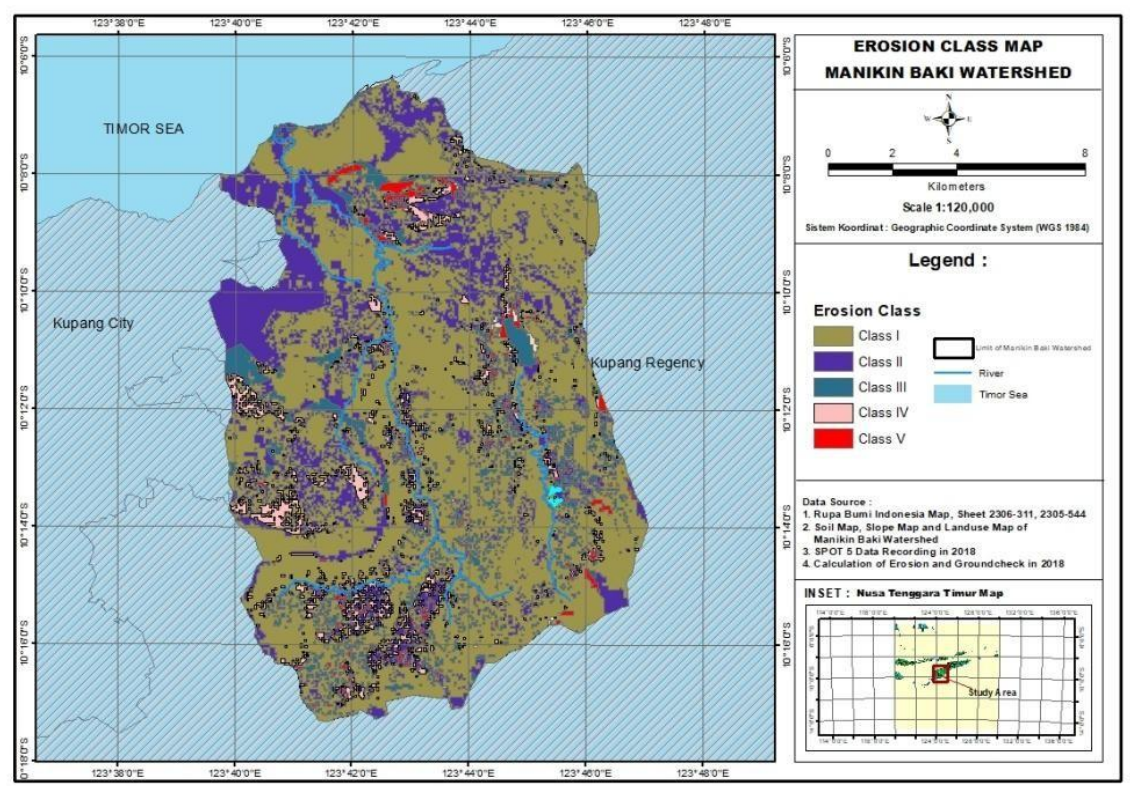

Fig. 3. Map of erosion class at Manikin Baki Watershed.

\section{Conclusions}

Soil erosion had been affected to some land uses at Manikin Baki watershed West Timor. The highest soil erosion occurred at dryland cropping $(61 \%)$, followed by settlement $(22 \%)$, dryland mixed cropping (14\%), and the lowest one was forest land (0.20\%). Dryland cropping induced more erosion, probably due to conventional practices of slash and burn for land clearing and its land cover. Although most of the land in Manikin Baki watershed was still at class I-III (1,7791.59 km2), area of 1,239.8 km2 (class IV-V) could not be ignored; otherwise, this number will increase. Conservation technology should have been done for reducing erosion level, especially in lower soil depth and high soil erodibility. Further study on determining the dominant factor each land uses need to be accomplished. Thus, local government and farmers will be able to do appropriate soil, and water conservation technology based on the land uses.

\section{Acknowledgement}

We grateful thank to Ministry of Higher Education, Research and Technology of Indonesia for funding support, and all technicians at Politani Laboratory for technical support. 


\section{References}

[1] Hidayat \& Mulyani. 2002. Lahan kering untuk pertanian dalam teknologi pengelolaan lahan kering. Pusat Penelitian Tanah dan agroklimat. Badan Litbang Pertanian. Departemen Pertanian. Jakarta (in Indonesia).

[2] Moata M.R.S., Takalapeta A., Puay Y., Kollo O, Tlonaen C. 2018. Monitoring of dryland soil quality to support food security in semi-arid region. Proceeding-agriculture national seminar $V$ "Sustainable dryland agriculture management to support food sovereignty. P: 46-52. ISBN : 978-602-64783-7-5.

[3] Puay O. \& Kuang S. 2017. Erosion level analysis at Baumata catchment area. Proceeding. $1^{\text {st }}$ national seminar on agricultural research, "optimalization of dryland natural resources to support food security in Nusa Tenggara region”, P.148-154. Research and Extension centre of Politani Kupang, Gita Kasih. Kupang. ISBN: 978-602-9114-90-4.

[4] Erol A, Kos Skan O, \& $\mathrm{Ba}_{s}$ Saran Ma. 2015. Socioeconomic modifications of the universal soil loss equation. Solid earth 6: 1025-1035.

[5] Borrelli P, Robinson Da, Felischer Lr, Lugato E, Ballabio C, Allewel C, Meusburger K, Modugno S, Schütt B, Ferro V, Bagarello V, Van Oost K, Montanarella L, \& Panagos P. 2013. An assessment of the global impact of 21 st century land use change on soil erosion. Nature communications.

[6] Barrow Cj. 1994. Land degradation. Cambridge university press. P 143.

[7] Bashagaluke Jb, Logah V, Opoku A, Sarkodie-Addo J, Quansah C. 2018. Soil nutrient loss through erosion: impact of different cropping systems and soil amendments in ghana. Plos one 13: e0208250.

[8] Naipal V, Ciais P, Wang Y, Lauerwald R, Guenet B, \& Van Oost Kv. 2018. Global soil organic carbon removal by water erosion under climate change and land use change during ad 1850-2005. Biogeosciences 15: 4459-4480.

[9] Pimentel D, Allen J, Beer A, Guinand L, Hawkins A, Linder R, Mclaughlin P, Meer B, Musonda D, Perdue D, Poisson S, Salazar R, Siebert S, Storner K. 1993. Soil erosion and agricultural productivity. World soil erosion and conservation. Cambridge university press.

[10] Pimentel D. 2006. Soil erosion: a food and environmental threat. Environment, development and sustainability 8: 119-137.

[11] Pimentel D, Harvey C, Resosudarmo P, Sinclair K, Kurz D, Mcnair M, Cris S, Shpritz L, Fitton L, Saffouri R, Blair R. 1995. Environmental and economic costs of soil erosion and conservation benefits. Science 267: 1117-1123.

[12] Mishra Pk \& Rai Sc. 2014. A cost-benefit analysis of indigenous soil and water conservation measures in sikkim himalaya, india. Mountain research and development ( $\mathrm{mrd}$ ). $34: 27-35$.

[13] Hammad Aa \& Borresen T. 2006. Socioeconomic factors affecting farmers perceptions of land degradation and stonewall terraces in central palestine. Environmental management 37: 380-394.

[14] Efthimiou N, Lykoudi E, \& Karavitis C. 2017. Comparative analysis of sediment yield estimations using different empirical soil erosion models. Hydrological sciences journal-journal des sciences hydrologiques. 62: 2674-2694.

[15] Wischmeier Wh \& Smith Dd. 1960. A universal soil loss estimating equation to guide conservation farm Planning. 7th international congress of soil sciences: 418-425.

[16] Erdogan Eh, Erpul G, \& Bayramin I. 2007. Use of usle/gis methodology for predicting soil loss in a semiarid agricultural watershed. Environmental monitoring and assessment 131:153-161.

[17] Ozcan, AU., Erpul, G., Basaran, M., Erdogan, HE., 2008. Use of USLE/GIS technology integrated with geostatistics to assess soil erosion risk in different land uses of Indagi Mountain Pass - Cankırı, Turkey. Environ Geol. :53: 1731-1741, DOI 10.1007/s00254-007-0779-6

[18] Asdak, C., (2007). Hidrologi dan Pengelolaan Daerah Aliran Sungai, Gadjah Mada University Press, Yogyakarta (in Indonesia) 
[19] Soto B, Basanta R, Perez R, Diaz-Fierros F. 1995. An experimental study of the influence of traditional slash- and-burn practices on soil erosion. Catena. 24: 13-23.

[20] Certini G. 2005. Effects of fire on properties of forest soils: a review. 143: 1-10.

[21] Are Ks, Oluwatosin Ga, Adeyolanu Ad, Oke Ao. 2009. Slash and burn effect on soil quality of an alfisol: soil physical properties. Soil and tillage research 103: 4-10.

[22] Ketterings qm, bigham jm, laperche v. 2000. Changes in soil mineralogy and texture caused by slashand- burn fires in sumatra, indonesia. Soil science society of america journal (sssaj) 64: 1108-1117.

[23] Kosmas C, Danalatos N, Cammeraat Lh, Chabart M, Diamantopoulos J, Farand R, Guitierrez L, Jacob A, Marques H, Martinez-Fernandez J, Mizara A, Moustakas N, Nicolau Jm, Olivers C, Pinna G, Puddu R, Puigdefabregas J, Roxo M, Simao A, Stamou G, Tomasi N, Usai D, Vacca A. 1997. The effect of land use on runoff and soil erosion rates under mediterranean conditions. Catena 29:45-59.

[24] García-Ruiz Jm. 2010. The effects of land uses on soil erosion in spain: a review. Catena 81: $1-11$.

[25]_Wei W, Chen L, Fue B, Huang Z, Wu D, \& Gui L. 2017. The effect of land uses and rainfall regimes on runoff and soil erosion in the semi-arid loess hilly area, china. Journal of hydrology 15:247-258. [26] Yang D, Kanae S, Oki T, Koike T, Musiake K. 2003. Global potential soil erosion with reference to land use and climate changes. Hydrological processes. Volume 17, issue 14. 